\title{
GROWTH, YIELD AND FRUIT QUALITY OF EGGPLANT (Solanum melongena L.) AS AFFECTED BY IRRIGATION INTERVALS AND FOLIAR APPLICATION OF SOME ANTITRANSPIRANTS. \\ Rakha, M.K.A. \\ Self Pollinated Vegetable Crops Research Department, Hort. Res. Inst. Agric. Res. Center, Giza, Egypt. \\ E-mail: Mohamed_rakha_elbehos@yahoo.com
}

\begin{abstract}
For facing acute problem of fresh water scarcity in the future to face the increasing population problem and also for cultivating newly reclaimed lands. So, two field experiments were conducted in the open field at farm Meat Salseil near Mansoura, City Dakahlia Governorate, Egypt during two successive early summer seasons of 2012 and 2013 on clay loam soil to investigate the effect of two treatments of irrigation intervals (10 and 20 days) and four treatments of foliar application from antitranspirants (control, Kaolin, Potassium silicate and dyriton ) as well as their interactions on growth, fruit quality, yield and its components of eggplant (Solanum melomgena L.) C.v Black Beauty. The experimental design was a split plot, where irrigation intervals were in the main plots and antitranspirants source allocated in the sub plots in a randomized complete block design with three replications.

The results obtained from this work could be summarized as follow:

- The effect of interaction between irrigation intervals and foliar antitranspirants had significant effect on all plant growth parameters during both seasons.

- The foliar application of antitranspirants, significantly enhance fruit quality compared with control treatment except acidity in the 1st season. As soon as spraying dyriton (4\%) under short irrigation intervals (10 days) recorded the highest values of T.S.S $\%$ and V.C.

- Also, the obtained results showed that application of antitranspirants were significantly increased on the most of yield parameters. The highest values were recorded with sprayed dyriton $4 \%$ compared with the other treatments.

- The interaction between irrigation intervals (10 and 20 days) and different foliar antitranspirants caused an increment on the most mentioned parameters of yield during both seasons.

- Generally, it could be concluded that the importance of determine the interactive effects between irrigation intervals and antitranspirants, to find out the optimum combinations for maximum early, total yield and fruit quality. It was found that irrigation intervals under 10 days with $4 \%$ dyriton sprayed as antitranspirants, had the best combination and it is recommended for eggplant grown under similar field condition in order to get higher economical yield.

Keywords: Eggplant, Irrigation intervals and antitranspirants, vegetative growth, fruit quality and yield.

\section{INTRODUCTION}

Eggplant (Solanum melongena L.) is generally enlisted as classical commodity for both local consumption and exportation. It is grown in most cultivated area in Egypt. According to FAO, 2012 production of eggplant is highly concentrated with $90 \%$ output coming from five countries. Egypt is the third producer $2.94 \%$ of total world production with amounted to over 1.229.790 million tones. It is one of the most important crops in summer season of Egypt. Eggplant fruits contain a considerable amount of carbohydrates, protein and vitamins (Mahamoud, 2000).
\end{abstract}


In last decades, Egypt suffers from reducing natural water resources for irrigation the cultivated area. On the other hand, irrigation water is considered as one the main factors that greatly affect on plant growth and productivity of eggplant.

The proper irrigation interval can play a major role in increasing the water use efficiency and the productivity by applying the required amount of water when it needed. On the other hand, the poor irrigation interval can lead to the development of crop water deficit and result in a reduced yield due to water and nutrient deficiency Abd El- Aal et al. (2008) studied the effect of water regime treatments on yield and its components of eggplant. The obtained results indicated that the bitter vigor plant growth, the heavier early and total yield were recorded when eggplant irrigated at shorter period i.e.at 10 days intervals. On the other hand, as the plant growth, moist soil is necessary for proper root development, as roots will not grow through a dry layer of soil. Frequent light irrigations results in shallow root systems which result in plants being stressed even in short periods of water deficient.

The best approach to early season irrigation is to begin with a full soil profile and encourage deep rooting by not watering routinely, but rather waiting until the $20 \%$ depletion of available water is reached at the appropriate monitoring depth. This may mean going from 5.7 days or longer between irrigation depending on the weather, the interval would be less in hot weather. Water stressed conditions encourage eggplant to develop its root system at deeper soil layers which retained more water (Aujla et al., 2007). There is increasing consciousness among agricultural scientists to reach

One of the most important tools to reach and better fruits in vegetable is the foliar application by some antitranspirants which aimed to reduce the free water on the leaves surface and reduce transpiration matter which improves growth and increase productivity. (Prakash et al., 1993 and Al Moftah and Al- Hamaid, 2005).It makes the overcome the plant to heat stress, thirst, salinity and prevents securities destruction with U.V which leads the prevention of injury and fungal diseases. Whereas the antitranspirants reduces the water losses during vegetative growth period and before or after fruits harvesting (Shafeek 1990; Abou-Hadid et al., 1994; Cszinszky, 2001; and Yadov and Dashora, 2003). Al-Moftah and Al-Hamaid 2005 stated that the cost of antitranspiration $1 / 3$ cost of the pesticide, fast absorption immediate and safe for the environment, no toxic effects on humans, animals and plants.

So, the objective of this study was to investigate the effect of irrigation intervals and antitranspirants and their interactions on growth, yield and fruit quality of eggplant.

\section{MATERIALS AND METHODS}

Two field experiments were carried out during both seasons successive seasons of 2012 and 2013 in a special farm at Meat Salseil City, Dakahlia Governorate, Egypt to evaluate the effect of two treatments of irrigation intervals 10 and 20 days and four foliar application of different antitranspirants as follow: 
1- Control (irrigation water)

2- Kaolin (aluminum silicate)

3-Potassium silicate

4-Dyriton (100\% acrylic) at the concentration of $4 \%$ each of them on growth, yield and yield components of eggplant.

The experimental design and treatments:

The experimental design combined 8 treatments were arranged in split plot in a randomized complete block design which were the simple possible combination between two treatments of irrigation intervals and four foliar application from antitranspirants. Each treatment was replicated three times. The irrigation regimes arranged in main plots, but the antitranspirants distributed in sub plots. Each sub experimental plot area was $12.8 \mathrm{~m}^{2}$ considered of four ridges; each was 0.8 width and $4 \mathrm{~m}$ in length.

Cultivation:

Seeds of eggplant (Solanum melongena L.) cv of Black Beauty were sown on 22 and 24 March of 2012 and 2013 seasons respectively on one side of ridges and $30 \mathrm{~cm}$ apart. The normal cultural practices commonly used in growing of eggplant were allowed. After 30 days from transplanting date, all experimental plots were divided in to two main groups first its plants irrigated at 10 days intervals, but the second, its plants irrigated at 20 days intervals. The antitranspirants were sprayed at 45 days old twice with 10 days intervals.

Chemical properties of the experimental soil were analyzed before cultivation at Institute Mansoura Lab. Agricultural Research Center (ARC) according to Page (1982) and the results are tabulated in Table 1.

Table1: physical and chemical analysis of the experimental soil during 2012 and 2013 seasons.

\begin{tabular}{|c|c|c|c|c|c|c|c|c|}
\hline Seasons & $\begin{array}{c}\text { Sand } \\
\%\end{array}$ & Silt \% & Clay \% & $\begin{array}{c}\text { Texture } \\
\text { class }\end{array}$ & $\mathbf{C a C o}_{3}$ & $\begin{array}{c}\text { Organic } \\
\text { matter \% }\end{array}$ & $\begin{array}{c}\text { pH } \\
\text { value }\end{array}$ & $\begin{array}{c}\text { E.C. } \\
\mathbf{d S m}^{-1}\end{array}$ \\
\hline 2012 & 27.2 & 31.5 & 41.3 & Clay- loam & 3.1 & 1.4 & 8.1 & 0.9 \\
\hline 2013 & 27.5 & 31.4 & 41.1 & Clay- loam & 3.2 & 1.2 & 7.9 & 0.8 \\
\hline
\end{tabular}

Table 1: continue

\begin{tabular}{|l|c|c|c|c|c|c|}
\hline \multicolumn{3}{|c|}{ Available (ppm) } & \multicolumn{4}{c|}{ Micro nutrients ( ppm) } \\
\hline $\mathrm{N}$ & $\mathrm{P}$ & $\mathrm{K}$ & $\mathrm{Fe}$ & $\mathrm{Zn}$ & $\mathrm{Mn}$ & $\mathrm{Cu}$ \\
\hline 40.15 & 11.3 & 306 & 35.90 & 2.55 & 65.4 & 5.50 \\
\hline 42.18 & 11.5 & 298 & 35.11 & 2.51 & 67.8 & 5.53 \\
\hline
\end{tabular}

Fertilization:

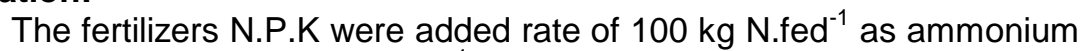
sulphate $(20.5 \% \mathrm{~N}), 60 \mathrm{~kg} \mathrm{P}_{2} \mathrm{O}_{5} \mathrm{fed}^{-1}$ as super phosphate $\left(15.5 \% \mathrm{P}_{2} \mathrm{O}_{5}\right.$ and $100 \mathrm{~kg} \mathrm{~K} \mathrm{fed}^{-1}$ as Potassium sulphate $\left(48 \% \mathrm{~K}_{2} \mathrm{O}\right)$. Phosphorus fertilizer was added to the soil before planting, while $\mathrm{N}$ and $\mathrm{K}$ fertilizers were added in three doses; after one month, two month from planting and third dose during following stage.

Sampling dates and data recorded:

Five plants were randomly taken from each experimental sub plot at 70 days after transplanting to determine the following parameters: 
1-Plant growth parameters :

-Plant height.

-Number of branches/plant.

-Number of leaves/plant.

-Dry weight /plant.

-Fresh weight/plant.

according to the method mentioned by Koller (1972).

- Total chlorophyll: leaf chlorophyll content was determined with A-Minloti SPAD chlorophyll-meter (Yadava, 1986). The chlorophyll-meter readings were recorded on the plant standing in the field on 2 nd leaf from the plant top.

2-Fruit quality:

Representative sample of eggplant fruits were randomly taken from each treatment at the fourth picking to determine the quality parameters as follows:

-Protein content (\%): was calculated by multiplying its $\mathrm{N}$ percentage by the $=$ Nitrogen \% X 6.25 .

- Vitamin $\mathrm{C}$ were determined according to the methods reported in A.O.A.C. (2000).

-Acidity \% according to A.O.A.C. (2000).

- Total soluble solids (TSS \%) was estimated using Galli 110 refractometer according to A.O.A.C. (2000).

3-Yield and its components:

Harvesting start after 90 days from transplanting and picking was taken. The following data were recorded yield as well as its components:

- Average number of fruits per plant.

-Average yield per plot $\mathrm{kg}\left(12.8 \mathrm{~m}^{2}\right)$.

- Early yield.

- Total fruit yield.

- Relative increase of total yield \% according to formula described by Andre (1972) as follows =

\section{Statistical analysis:}

$$
\frac{\text { treatment-control }}{\text { control }} \times 100
$$

The obtained data were subjected to statistical analysis as split plot in a randomized complete block design with three replicates in the both growing seasons according to the technique of analysis of variance (ANOVA) and the least significant differences (L.S.D.) method was used by Gomez and Gomez (1984).

\section{RESULTS AND DISCUSSION}

The obtained results are presented in this part under separate headings including characteristics of plant vegetative growth, fruit quality, yield and its components as affected by irrigation intervals and foliar application of antitranspirants sources as well as their interactions during both seasons of the experiments 2012 and 2013 as follows:

\section{1-Vegetative growth characteristics:}

Data of vegetative growth characteristics, i.e., plant height, number of leaves, branches / plant, leaves area / plant, total chlorophyll as well as fresh and dry weight as affected by irrigation intervals and foliar application of antitranspirants sources are given in Table 2 . 
J. Plant Production, Mansoura Univ., Vol. 5 (12), December, 2014

2- 


\section{Effect of irrigation intervals:}

The effect of irrigation intervals on vegetative growth parameters indicated that shorter irrigation interval had significant increases in all growth measures of eggplant in two seasons. (Table 2). Similar results were obtained by Abbas et al. (1999); Suryanarana and Venkateswarlu (1981); Kirnak et al. (2001); El-Galfy (2005); Abbas (2007); Ibrahim and Selim (2007); Boamah et al. (2010); Farhad et al. (2010); Bahawireth (2011); Pirboneh et al. (2012) and Makarlm et al. (2014). It is well know that plant growth is a function of total moisture stress which is decreased, the solubility of salts in the soil will increase. Also, supplying plants with adequate moisture may accede rate the physiological process in the plant. On the other hand it increases translocation of metabolites which in turn might increased and favored the accumulation of organic compounds in the plants. It could be concluded that, the reduction in the plant growth measurements was propounded when eggplant were subjected to high soil moisture stress (irrigation at 20 day interval). Such response might be attributed to lake of water absorbed, inhibition of meristemic activity and reduction in photosynthetic efficiency under the prolonged irrigation interval. Shaheen (1996), Abbas et al. (1999). Sawan et al. (2001), Al- Shaikh (2004), Abd ElAal et al. (2008), Boamah et al. (2010) and Bahawireth (2011) who studied the effect of the irrigation interval on eggplant and other crops. They found that irrigation interval significantly affected in all tested characters as stem length, number of branches, fresh and dry weight and recorded the highest values under shorter irrigation interval (12 day).

\section{Effect of antitranspirants source:}

It is clear from the data presented in Table 2 that, all growth parameters were significantly increased in response to spraying all foliar application of antitranspiration as compared the untreated plants (water). The application of dyriton, $4 \%$ had the best vigor plant growth followed in descending order by that eggplant which treated with potassium silicate. On the other hand contrary, the less vigor growth was detected with control plants (treated with water). These increases were true and statistical in the two season of the experiment. It could be summarized that, foliar application of antitranspirants gained superiority in plant growth characters if compared with control treatments, and within the antitranspirants the application of dyriton gave the greatest vigor of plant growth. These results were agreement with findings of Kadbance and Munge (1997), Mahfouz (1997), Karuppiah et al. (2003) and Yadov and Dashora (2003) and Del Amor et al. (2010). The use of antitranspirants may be helped in keeping healthy plant during the growing season, so it is quite sufficient from our results here to recognize that the increment happened in vegetative growth on eggplant, i.e., plant length, number of leaves and shoots, fresh and dry weights treated with antitranspirants such as dyriton comparatively to these of control was possibly due to from condition, and second is the increase of water potential at a time when the growth plant was more dependants on water status than on photosynthesis. This positive for vegetative growth has reflection on total fruits yield and its contents. The obtained results are in good harmony with those of Upadhayaya and Mathur (1992); Prakash et al. (1993); Gawish and 
Fatahallah (1997) and Karuppiah et al. (2003) who studied the effect of different antitranspirants (kaolin, phenyl mercuric acetate, salicylic acid and liquid paraffin) on the growth, photosynthesis of eggplant cv. Annamalai. Antitranspirants significantly influenced the plant biomass, number of branches, plant height, leaf area and number of flower. Kaolin (7.5\%) spray antitranspirants affected the photosynthetic characters such as net photosynthetic rate, stomatal conductance, intercellular $\mathrm{Co}_{2}$ concentration, transpiration and relative water content (RWC). Maximum net photosynthetic rate and (RWC) and minimum transpiration were observed with Kaolin (7.5 $\%)$.

Effect of interaction between irrigation intervals and antitranspirants:

Results illustrated in Table 2 represent the interaction effect of irrigation intervals and antitranspirants treatments on eggplant growth parameters in both two experimental seasons. From those results, it could be observed that treating eggplant with dyriton or $\mathrm{K}_{2} \mathrm{Sio}_{3}$ were superior under all irrigation interval in comparison with other interaction treatments. It could be observed that plants irrigated at 10 days and spraying with dyriton $4 \%$ recorded the highest mean values of all measured parameters, while spraying with water at 20 days treatment recorded the lowest ones during both seasons. The obtained results indicated that the better vigor plant growth and dry weight were recorded with spraying of the antitranspirants at 10 days. The obtained results are in accordance with those reported by Gawish (1992a); Aujla et al. (2007); Anwar (2005); Bafeel and Moftah (2008) and Abd El- Aal et al. (2008).

2-Fruit quality:

Data concerning fruits quality; TSS \%, V.C (mg/ $100 \mathrm{~g})$, acidity \% and protein $\%$ as affected by water regime treatments and foliar applications of different antitranspirants as well as their interactions are presented in Table (3).

\section{Effect of irrigation intervals:}

The effect of irrigation intervals reviewed in Table 3 show that all previous parameters were decreased with increasing irrigation intervals. On the other hand, irrigation intervals significantly affected in TSS \%, V.C, except acidity $\%$ in the $1^{\text {st }}$ season. These results were obtained by Uppal et al. (1997); Saied (2000) and Abd El-Aal et al. (2008) who studied the effect of two water regime treatments on the nutritional value of eggplant. They found that better physical and chemical properities of fruits all them were recorded when eggplant irrigated at shorter period (10 days intervals).

Effect of antitranspirants source:

Concerning the effect of different sources of antitranspirants on fruit quality, data in Table 3 clearly show that sources of antitranspirants significantly enhance fruit quality as compared with control except acidity $\%$ in the $1^{\text {st }}$ season. It is clearly that spraying either $\mathrm{K}_{2} \mathrm{SiO}_{3}$ or dyriton pushed to increase the previous parameters except acidity was decreased during both seasons. These results were obtained by Abd El-Aal et al. (2008) and Saif Eldeen and Abd El- Hameed (2010). 
Effect of interaction between irrigation intervals and antitranspirants:

Data illustrated in Table 3 show the reflection on fruit quality of eggplant fruits in response to the interaction between irrigation intervals and foliar antitranspirants during both seasons. Spraying dyriton $4 \%$ under short irrigation intervals 10 days recorded the highest values of TSS $\%$ and V.C.and protein \%. While acidity \% recorded the highest values with control plants. In addition, protein \% was significantly affected by adding foliar antitranspirants under both irrigation intervals during both seasons.

\section{3-Yield and yield components:}

Yield and its components could be considered to be the mirror of all growth features. The results given in Table 4 presented the response of yield and its components of eggplant, i.e., number of fruits per plant, average yield / plot $\left(12.8 \mathrm{~m}^{2}\right)$, early yield / fed, total yield/ fed and relative increase of total yield $\%$ to irrigation intervals $(10,20$ days) and different foliar antitranspirants (control, Kaolin, $\mathrm{K}_{2} \mathrm{Sio}_{3}$ and dyriton ).

\section{Effect of irrigation intervals:}

Concerning to the effect of the irrigation intervals it had significant increases in yield and yield components parameters during both seasons (Table 4). The highest values were obtained from 10 days intervals treatment during both seasons, the values of yield / plot $\left(12.8 \mathrm{~m}^{2}\right)$ were 67.28 and $68.20 \mathrm{~kg}$ in $1^{\text {st }}$ and $2^{\text {nd }}$ season, respectively. The early plant fruits yield responses the same trend similar to total tonnage yield. The resulted could be abstracted that, the proper system of irrigation regime for eggplant at least under the condition of this travel was the irrigation at intervals of 10 days. Thus these results are quite expected since prolonging irrigation intervals caused water stress which decreased the activity of meristimatic tissue and caused a dwarfing in eggplant plants and decreased leaves and shoots which decreased the productivity of plant. The higher total fruits yield obtained from irrigation the eggplant at shorter period, 10 days intervals may be due to increase in one or more of the estimated attributes either in fresh or dry weight of where eggplant. However, the picture reflected significant increase on, fresh and dry weight of plant. So, these increments may be led to the favorable increases in productivity of eggplant. The obtained results are in good harmony with those to El-Marsafawy et al. (2000) on potato; Abd El-Aal et al. (2008) on eggplant; Farhad et al. (2010)on potato and Amiri et al. (2012) who studied the effects of three irrigation intervals (no irrigation 6 days intervals and 12 days intervals) on eggplant. The results of this study show that among irrigation treatments, the highest amount of number of fruits per $\mathrm{m}^{2}$ and fruit yield were observed in 6 days intervals irrigation with total water use of $441(\mathrm{~mm})$. Also Pirboneh et al. (2012) who reported that irrigation of eggplants every 6 days and application of $2 \mathrm{~cm}$ mulch in per plant results in the highest yield with 51.1 ton / ha attributed. 
J. Plant Production, Mansoura Univ., Vol. 5 (12), December, 2014

3- 
Rakha, M.K.A.

4- 


\section{Effect of antitranspirants source:}

Data presented in Table 4 show that the effect of antitranspirants source on yield parameters. It was found increased significantly with sprayed antitranspirants in two seasons. The highest values were recorded with sprayed dyriton $4 \%$ compared with the other treatments. On the other hand, all antitranspirants treatment caused a promosion and an increment in early yield, and total fruit yield compared with control plants. Moreover, within the antitranspirants which used, the application of dyriton gained the heaviest total yield 22.09 and 22.21 ton/fed., early yield 8.10 and 8.21 ton / fed. and relative increase was $13.40 \%$ and $13.26 \%$ in both seasons respectively.

In could be concluded that the antitranspirants as foliar for eggplant enhanced the total fruits yield and its components, and the application of dyriton $4 \%$ gave the best fruits yield. This result however, point to the good effect of the antitranspirants which are biodegradable organic film formulated to protect plants from injury of shock caused by excessive transpiration of water loss through different vegetative plant organs, consequently enhancing the vegetative growth. The highest vegetative growth has reflected on fruits yield and its quality. In this study, dyriton as antitranspirant at $4 \%$ was still the most superior effective on in inducing the heaviest fruits yield. In this respect, many other investigators had results which in good harmony with those obtained by Cszinszky (2001); Govindakrishnan et al. (2003) on potato; Al-Moftah and Al- Hamaid (2005) and Abd El- Aal et al. (2008) who found that foliar spraying of the antitranspirants gained more fruits yield if compared with no treated plants. Moreover, the application of dyriton at $4 \%$ twice resulted in the best growth yield and fruits quality.

\section{Effect of interaction between irrigation intervals and antitranspirants:}

Concerning to the effect of interaction between irrigation intervals and antitranspirants on yield and its components (Table 4). The interaction had significant effects in all previous parameter during both seasons. No significant effects were detected between the foliar application and irrigation intervals in number of fruits / plant, in both seasons. On the other hand, reviewing data respecting yield and its components, the interaction caused an increment an all mentioned parameters in both seasons. The highest values were recorded with sprayed eggplant with dyriton $4 \%$ under 10 days of irrigation intervals. It could be suggested that water plays great role has important function in all physiological processes starting from mineral absorption from the soil up to building different components inside the plant and finally the yield is the sum of plant growth and development. Similar results were obtained by Gawish (1992a) and Franciso et al. (2014). 


\section{REFERENCES}

Abbas, F.A.; M.A. El-Eman and N. A. Anton (1999). Effect of irrigation intervals on two rapesed varieties, Third conf. of on-farm irrigation and agroclimatology, 1(1): 37. 25-27.

Abbas, J. A. (2007). Effect of potassium fertilization and irrigation intervals on growth and yield of eggplant (Solanum melongena L.) Jordan J. Agric. Sci., 3 (3): 350- 361.

Abd El-Aal, F. S.; M. M. Abdel Mouty; A. H. Ali (2008). Combined effect of irrigation intervals and foliar application of some antitranspirants on eggplant growth, fruits yield and its physical and chemical properties. Res. J. Agric. Bio. Sci., 45 (5): 416 - 423.

Abou- Hadid , A. F.; M. M. Saleh ; S. A. Shanans and T. M. G. El-Abd (1994). A comparative study between different means of protection on the growth and yield winter tomato crop. Acta Horti., (366) : 105112.

Al-Moftah, A. E. and A. R. Al-Hamaid (2005). Response of vegetative and reproductive parameters of water stressed tuberose plants to vapor gard and kaolin antitranspirants.Arab.Gulf.J.Sc.Res.23 (1): 7-14.

Al-Shaikh, A. A. (2004). Effect of irrigation intervals, Nitrogen and phosphorus application on forage yield, carbohydrates and protein content of guar (Cyamopsis tetragonoloba L.) in the central region of Saudi Arabia Saudia J. Bio. Sci., 11 (1): 3-9.

Amiri, E. ; A. A. Gohari and Y. Esmailian (2012). Effect of irrigation and nitrogen on yield, yield components and water use efficiency of eggplant. African J. Biotechnolongy., 11(13):3070 - 3079.

Andre, K. (1972). The great increase in relatitive volataibility on Real Wag in the United States. 210 Meeting Papers 674 Society for Economic Dynamics.

Anwar, R. S. M. (2005). Response of potato crop to biofertilizers irrigation and antitranspirants under sandy soil condition. These Ph.D. Horti. and vegetable., Fac. Agri., Zagazig Univ., Egypt.

A.O.A.C. (2000). "Official methods of Analysis" Twelfth Ed. Publical Chemists, Benjamin, France Line Station, Washing D.C.

Aujla M. S. ; H.S. Thind and G. S. Buttar ( 2007). Fruit yield and water use efficiency of eggplant (Solanum melongena L.) as influenced by different quantities of nitrogen and water applied through drip and furrow irrigation. Scientia Hort., 112: 142- 148.

Bafeel, S. O. and A. E. Moftah (2008). Physiological response of eggplant grown under different irrigation regimes to antitranspirants treatments Saudi J. Bio. Sci., 15(2): 259 - 267.

Bahawireth, M. A. M. (2011). Physiological and yield performance of some okara and eggplant genotypes under water stress condition Ph.D. Thesis Department Hort. and Veg. Crop. Assuit Univ., Egypt.

Boamah, P. O.; L. L. Sam- Amoah and J. D. Owusu- Sekyeree (2010). Effect of irrigation intervals on growth and development of tomato under sprinker. Asian J. Agric. Res., 4: 196 - 203. 
Cszinszky, A. A. (2001). Yield response of fresh market tomatoes to micro irrigation and antitranspirants rates on sand. Socity for Tropical Hort., 43: $11-19$.

Del Amor, F. M.; P. Cuadro; D. J. Walker, J. M. Camgra and R. Madri (2010). Effect of foliar application of antitranspirant on photosynthesis and water relations of pepper plants under different levels of $\mathrm{Co}_{2}$ and water stress. J. Plant Physiol., 167 (15): 1232 - 1238.

El- Galfy, A. K. (2005). Effect of some irrigation treatments on yield, yield components and seed quality characteristics of some faba bean (Vicia faba L.) varieties. Annals of Agric. Sc. Moshtohor, 43 ( 1) : 51 62.

El- Marsafawy, S. M.; I. S.Bengaman, N. M. El-Mowelhi and S. A. AbdelHafez (2000). Effect of different irrigation regimes on simulated potato productivity and water needs. Egypt J. Appl. Sci., 15 (12): 350 -365 .

F.A.O. (2012). Faostat Agricultural Data. Agricultural production crops primary. United Nations Food and Agriculture Organization. Retrieved, 18 September.

Farhad, M.; M. Zardash;M.B. Abd Elahi ; M. H. Rasouli Sedghiani and H.Nazarli (2010). Effect of irrigation intervals on yield and plant characteristics of potato (Solanum tuberosum L. ) Indian J. Crop Sci., 12 (3): 47265 - 278.

Franciso, M. D.; J. W. David ; M. C. Jose and M. Ramon ( 2014 ). Effect of foliar application of antitranspirants on photosynthesis and water relation of pepper plants under different levels of $\mathrm{Co}_{2}$ and water stress. J. Plant Physiology, (3): $851-869$.

Gawish, Ragaa A. R. (1992a). Effect of antitanspirants application on snap bean (Phaseolus vulgaris ) grown under different irrigation regimes. I Growth, transpiration rate and leaf content of water NPK and total carbohydrates. Minufiya J. Agric. Res., 17 (3): 1285 - 1308.

Gawish, Ragaa A. R. and M. A. Fatahallah (1997). Modification of irrigation requirements of tora (Colcasia esculenta $\mathrm{L}$.) through the application of antitranspirants. Minufiya J. Agric. Res., 22(5): 1353 - 1387.

Gomez, K. A. and A. A.Gomez (1984). Statistical procedure for agricultural research $2^{\text {nd }}$ ed. John Willy and Sons Pub., $139-153$.

Govindakrishnan, P. M.; D. C. Ghosh and S. S. Lal (2003). Effect of lime and kaolin reflectants in early planted crop of potato. J. Indian Potato Association, $1 / 2: 71-72$.

Ibrahim, E. A. and E. M. Selim (2007). Effect of irrigation intervals and nitrogen fertilizer rates on summer squash (Cucurbita pepo L.) growth, yield, nutritional status and water use efficiency. J. Agric, Sci. Mans. Univ., 32 (12): 9861- 9874.

Kadbance, V. T. and H. B. Munge (1997). Influence of kaolin sprays on leaf area, dry matter production and yield of summer mang bean. J. Maharashra Agric.Univ.1997, Publ. 1998, 22 (3): 292 - 295. 
Karuppiah, P. S.; S. Rameshkumar, K. Shah and R. Marimutha (2003) Effect of antitranpirants on growth, photosynthetic rate and yield characters of brinjal. Undian Journal of plant physiology. 2, $189-192$.

Kirnak, H.; C. Kaya; I. Tas and D. Higgs (2001). The influence of water deficit on vegetative growth, physiology, fruit yield and quality in eggplant. Bulgarian J. Plant Physiol., 27 (3- 4) : $34-46$.

Koller, H. R. (1972). Leaf area and leaf weight relationship in soybean canopy. Crop Sci., 12: $180-183$.

Mahamoud, H. A. F. (2000). Effect of sulphur and phosphorus on some eggplant cultivars and calcareous soil conditions. Res. Bull. Fac. of Agric. Cairo Univ., 51 (2): 209 - 225.

Mahfouz, S. A. S. (1997). Effect of some antitranspirants of roselle plant under limited irrigation condition. M. Sc. Thesis, Fca. Agric., Minufiya Univ. Egypt.

Makarlm, A. H.; E. Hend ; M. Ibrahim and A. A. Yousef (2014). Effect of irrigation intervals on growth and chemical composition of some curcuma spp. Plants. Bio.Sci., 6 (2) 140 - 145.

Page,A. L. (1982). Methods of soil Analysis 2nd Ed., Part1, Soil Sci. Soc. Amer., Madison, Wisc., USA.

Pirboneh, H. ; M. Ghasemi ; A. A. Gohari; B. Bahari and B.Zahra- Bazkiyaei ( 2012 ). Effect of irrigation and straw mulch on yield and yield components of eggplant (Solanum melongena L.) Intl. Res.J. Appl. Basic Sci., 3(1): 46 - 51.

Prakash, M. ; K. Ramach andran and M. Nagaajan (1993). Effect of antitranspirants on the morphoysiology of brinjal. South Indian, Horti. Abstr., 64 (5): 3657.

Saied, M.M. (2000). Effect of irrigation intervals, furrow irrigation system and nitrogen fertilizer levels on sugar beet yield and its water relations at north delta, J. Agric. Sci. Mans. Univ., 25 (7): 4737 - 4745.

Saif Eldeen, U. M. and A. M. Abd El-Hameed (2010). Effect of farmyard manure, irrigation water quantity and some antitranspirants on glope artichoke in sandy soil. J. Agric. Sci. Mans. Univ., 1(2) 185- 209.

Sawan, O. M.; A. H. Amer and M. El-Desuki (2001). Effect of irrigation and organic fertilizer on sugar pea ( Pisum sativum L. ) under Shak ElOwinat condition. Ann. Of Agric.Sci.Moshtohor, 39 (2) : 1251 - 1264.

Shafeek, R. H. (1990). Studied on the growth and yield of pepper grown under plastic treatments. M. Sci. Thesis Fac. Agric. AlAzhar Univ. Cairo, Egypt.

Shaheen, A. H. (1996). Effect of irrigation frequency and fertilization on pea growth yield, yield components and total uptake of some micronutrients. Ann. Agric. Sci. Moshtohor, 34 (2): 669 - 689.

Suryanarana,V.and A.Venkateswarlu. (1981). Effect of irrigation frequency, antitranspirants and mulching on growth and yield of tomato. $\mathrm{J}$. Horticulture, 9 (2): 1 - 7.

Upadhayaya, S. D. and C.M. Mathur (1992). Effect of antitranspirant on the physiological characteristics of wheat. Advances in Plant Sci., 5 (2) : $457-463$. 
Uppal, H. S.; P. Suraj; S. S. Mahal; R. Bhunpider, S.Prakash and B.Kaur (1997). Effect of time of $\mathrm{K}$ application and with drarwal of irrigation on yield and chip quality of potato. J. of potassium Res., 13 (3-4): 277 287.

Yadava, U. L. (1986). A rapid and non-destructive method to determine chlorophyll in intact leaves. Hort. Sci., 21: 1449-1450.

Yadov, N. R. and L. K. Dashora (2003). Shelf-life of sweet peper (Capsicum annuum L.) CV. California Wander as influenced by benzyladenine and vapor grad. Advances in Hotriculture and forestay, 9: 215 - 221.

تـأثير فترات الرى ومضـادات النتح على النمـو و المحصـول وصفات الجودة فى

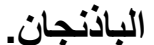

محمد خفاجى عبد الرحيم رخا. قسم بحوث الخضر ذاتية التلقيح- معهد بحوث البساتين - مركز البحوث الزراعيةـ مصر.

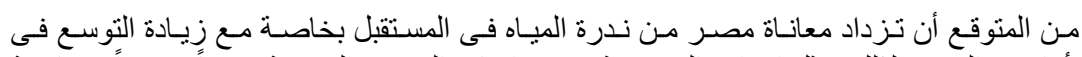

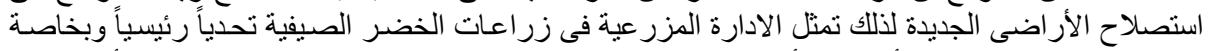

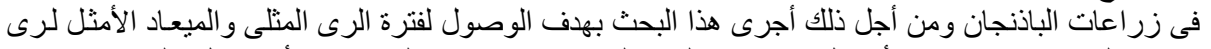

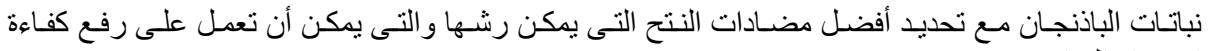

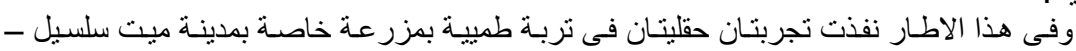

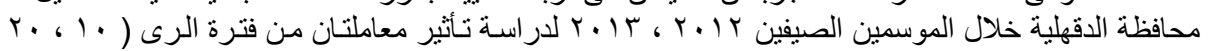

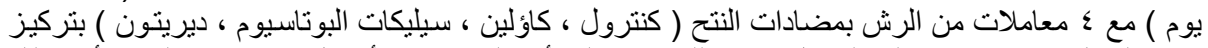

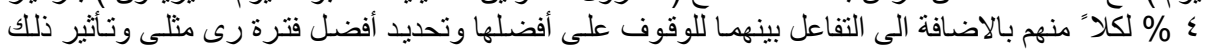

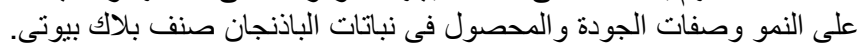

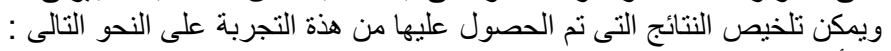

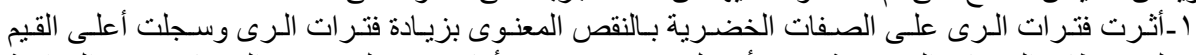

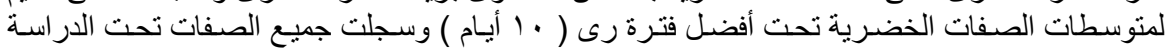

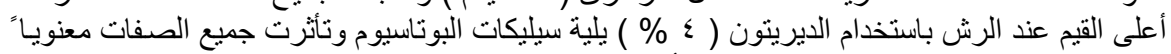

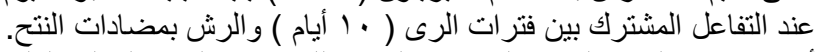

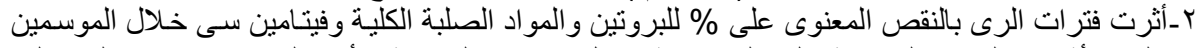

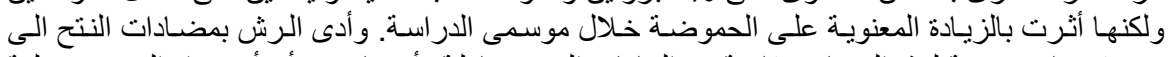

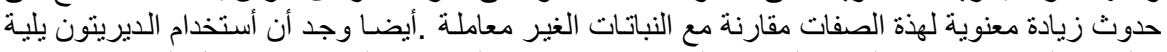

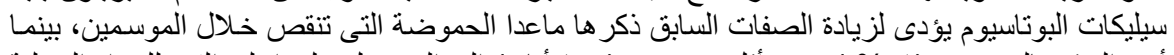

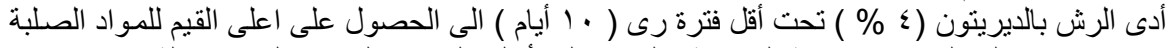

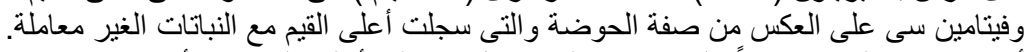

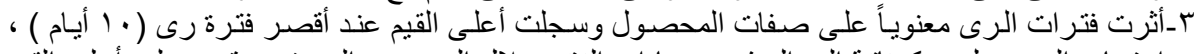

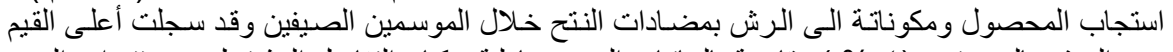

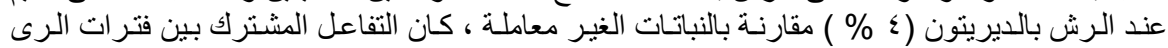

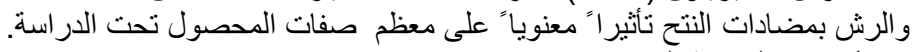

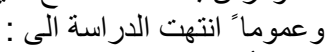

اــ أهمية كلاً من فترات الرى و الرش بمضادات النتح للحصول على أفضل صفات جودة وأعلى محصول

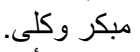

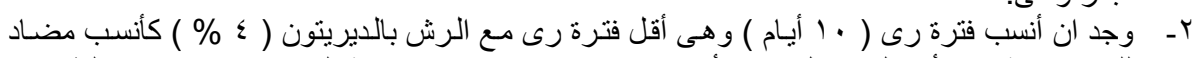

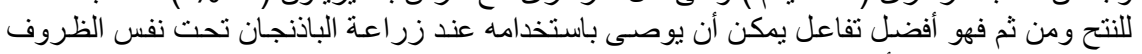
الحقلية للحصول على أعلى محصول اقتصنادى. 
J. Plant Production, Mansoura Univ., Vol. 5(12): 2069- 2083, 2014

Table (2): Effect of irrigation intervals, antitranspirants and their interaction on vegetative growth characteristics of eggplants during seasons of 2012 and 2013.

\begin{tabular}{|c|c|c|c|c|c|c|c|c|c|c|c|c|c|c|c|}
\hline & \multirow{2}{*}{\multicolumn{2}{|c|}{$\begin{array}{c}\text { Plant height } \\
\text { (cm ) }\end{array}$}} & \multirow{2}{*}{\multicolumn{2}{|c|}{$\begin{array}{c}\text { No. of Leaves / } \\
\text { plant }\end{array}$}} & \multirow{2}{*}{\multicolumn{2}{|c|}{$\begin{array}{l}\text { No. of } \\
\text { branches / } \\
\text { plant }\end{array}$}} & \multirow{2}{*}{\multicolumn{2}{|c|}{$\underset{\text { plant) }}{\text { Fresh weight ( } g /}$}} & \multirow{2}{*}{\multicolumn{2}{|c|}{$\begin{array}{c}\text { Pry weight ( } \mathrm{g} / \\
\text { plant ) }\end{array}$}} & \multirow{2}{*}{\multicolumn{2}{|c|}{$\begin{array}{l}\text { Leaf area / plant } \\
\left(\mathrm{cm}^{2}\right)\end{array}$}} & \multirow{2}{*}{\multicolumn{2}{|c|}{$\begin{array}{c}\text { Chlorophyll } \\
\text { Reading (SPDA) }\end{array}$}} \\
\hline & & & & & & & & & & & & & & & \\
\hline & & $1^{\text {st }}$ & $2^{\text {nd }}$ & $1^{\text {st }}$ & $2^{\text {nd }}$ & $1^{\text {st }}$ & $2^{\text {nd }}$ & $1^{\mathrm{st}}$ & $2^{\text {nd }}$ & $1^{\mathrm{st}}$ & $2^{\text {nd }}$ & $1^{\text {st }}$ & $2^{\text {nd }}$ & $1^{\text {st }}$ & $2^{\text {nd }}$ \\
\hline \multicolumn{16}{|c|}{ A : Irrigation period } \\
\hline \multicolumn{2}{|c|}{10 days } & 75.35 & 77.01 & 33.29 & 34.42 & 5.33 & 5.36 & 317.19 & 319.85 & 56.64 & 57.13 & 4538.22 & .17 & 74.98 & 75.10 \\
\hline \multicolumn{2}{|c|}{20 days } & $\begin{array}{ll}10.00 \\
73.95 \\
\end{array}$ & 74.40 & 33.00 & 33.21 & 5.29 & 5.33 & 315.21 & 316 & 56.28 & 56.48 & \begin{tabular}{|l|}
4508.31 \\
\end{tabular} & 4535.39 & 74.50 & 74.68 \\
\hline \multicolumn{2}{|c|}{ LSD } & 0.07 & 0.05 & 0.22 & 0.24 & 0.03 & 0.01 & 2.41 & 1.51 & 1.57 & 1.54 & 5.11 & 2.79 & 0.26 & 0.18 \\
\hline \multicolumn{16}{|c|}{ B: Antitranspirants source } \\
\hline \multicolumn{2}{|l|}{ Water } & 72.08 & 71.79 & 30.43 & 30.61 & 4.83 & 4.87 & 286.11 & 289.77 & 51.09 & 51.73 & 4391.81 & 4419.39 & 73.86 & 73.90 \\
\hline \multicolumn{2}{|c|}{ Kaolin } & 80.57 & 76.41 & 32.80 & 32.95 & 5.11 & 5.15 & 305.98 & 307.69 & 54.86 & 54.91 & 4583.72 & 4622.88 & 74.68 & 74.79 \\
\hline \multicolumn{2}{|c|}{$\mathrm{K}_{2} \mathrm{SiO}_{3}$} & 83.39 & 86.34 & 35.01 & 35.48 & 5.36 & 5.42 & 327.89 & 330.72 & 58.61 & 59.08 & 4716.62 & 4800.11 & 75.40 & 75.52 \\
\hline \multicolumn{2}{|c|}{ Dyriton } & 87.24 & 89.35 & 37.31 & 37.68 & 5.58 & 5.64 & 341.56 & 337.69 & 60.98 & 60.31 & 5013.52 & 5090.83 & 76.63 & 76.78 \\
\hline \multicolumn{2}{|c|}{ LSD at $5 \%$} & 0.23 & 0.25 & 0.49 & 1.06 & 0.05 & 0.04 & 4.19 & 2.39 & 1.32 & 0.90 & 4.91 & 5.88 & 0.28 & 0.23 \\
\hline \multicolumn{16}{|c|}{ C : Interaction effect of irrigation intervals and antitranspirants source } \\
\hline \multirow{4}{*}{$\begin{array}{l}10 \\
\text { days }\end{array}$} & Water & 73.90 & 72.89 & 30.50 & 30.63 & 4.85 & 4.89 & 287.11 & 290.98 & 51.26 & 51.96 & 4400.32 & 4450.68 & 73.91 & 73.98 \\
\hline & Kaolin & 82.33 & 82.49 & 32.92 & 33.00 & 5.13 & 5.16 & 307.64 & 309.91 & 54.93 & 55.38 & 4600.91 & 4640.71 & 74.70 & 74.89 \\
\hline & $\mathrm{K}_{2} \mathrm{SiO}_{3}$ & 86.42 & 87.31 & 35.21 & 35.67 & 5.38 & 5.42 & 329.58 & 332.11 & 58.85 & 59.30 & 4726.82 & $\varepsilon \wedge r \cdot$ ro & 75.86 & 75.90 \\
\hline & Dyriton & 90.11 & 90.58 & 37.51 & 37.80 & 5.64 & 5.71 & 343.35 & 348.77 & & 62.28 & 5060.73 & $0.94 . \pi \leq$ & 76.91 & 76.93 \\
\hline \multirow{4}{*}{$\begin{array}{l}20 \\
\text { days }\end{array}$} & Water & 72.00 & 70.44 & 30.41 & 30.52 & 4.82 & 4.86 & 285.11 & 287.32 & 50.09 & 51.31 & \begin{tabular}{|l|}
4380.35 \\
\end{tabular} & 4410.19 & 73.82 & 73.89 \\
\hline & Kaolin & 79.15 & 75.48 & 32.56 & 30.79 & 5.07 & 5.10 & 304.99 & 304.86 & 54.29 & 54.43 & \begin{tabular}{|l|}
4571.81 \\
\end{tabular} & 4611.35 & 74.25 & 74.33 \\
\hline & $\mathrm{K}_{2} \mathrm{SiO}_{3}$ & 83.29 & 85.34 & 34.97 & 35.39 & 5.33 & 5.38 & 326.23 & 328.11 & 58.23 & 58.59 & \begin{tabular}{|l|}
4711.69 \\
\end{tabular} & \begin{tabular}{|l|}
4795.69 \\
\end{tabular} & 75.11 & 75.26 \\
\hline & Dyriton & 87.10 & 88.91 & 37.22 & 37.42 & 5.53 & 5.58 & 339.18 & 336.18 & 60.56 & 60.03 & \begin{tabular}{|l|}
4981.82 \\
\end{tabular} & 5041.18 & 75.99 & 76.13 \\
\hline \multicolumn{2}{|c|}{ LSD at $5 \%$} & 0.70 & 0.72 & 1.07 & 1.42 & 0.06 & 0.07 & 3.40 & 2.51 & 1.87 & 1.27 & 7.48 & 11.96 & 0.26 & 0.20 \\
\hline
\end{tabular}


Table(3): Effect of irrigation intervals, antitranspirants and their interaction on fruit quality of eggplants during seasons of 2012 and 2013.

\begin{tabular}{|c|c|c|c|c|c|c|c|c|c|}
\hline \multirow{2}{*}{ Treat. } & & \multicolumn{2}{|c|}{$\begin{array}{l}\text { Protein } \\
\%\end{array}$} & \multicolumn{2}{|c|}{ T.S.S \% } & \multicolumn{2}{|c|}{$\begin{array}{c}\text { V. C. } \\
\text { ( } \mathrm{mg} / 100 \mathrm{mg})\end{array}$} & \multicolumn{2}{|c|}{$\begin{array}{l}\text { Acidity } \\
\%\end{array}$} \\
\hline & & $1^{\text {st }}$ & $2^{\text {nd }}$ & $1^{\mathrm{st}}$ & $2^{\text {nd }}$ & $1^{\text {st }}$ & $2^{\text {nd }}$ & $1^{\text {st }}$ & $2^{\text {nd }}$ \\
\hline \multicolumn{10}{|c|}{\begin{tabular}{|c|c|} 
A : Irrigation period \\
\end{tabular}} \\
\hline \multicolumn{2}{|l|}{10 days } & 18.20 & 18.41 & 4.41 & 4.45 & 1.61 & 1.63 & 0.429 & 0.431 \\
\hline \multicolumn{2}{|l|}{20 days } & 18.11 & 18.29 & 4.38 & 4.42 & 1.59 & 1.61 & 0.456 & 0.460 \\
\hline \multicolumn{2}{|l|}{ LSD } & 0.36 & 0.31 & 0.21 & 0.23 & 0.09 & 0.06 & NS & 0.004 \\
\hline \multicolumn{10}{|c|}{ B: Antitranspirants source } \\
\hline \multicolumn{2}{|l|}{ Water } & 16.41 & 16.61 & 3.98 & 4.00 & 1.59 & 1.62 & 0.439 & 0.422 \\
\hline \multicolumn{2}{|l|}{ Kaolin } & 17.22 & 17.33 & 4.31 & 4.35 & 1.63 & 1.66 & 0.418 & 0.420 \\
\hline \multirow{2}{*}{\multicolumn{2}{|c|}{$\mathrm{K}_{2} \mathrm{SiO}_{3}$}} & 18.32 & 18.46 & 4.44 & 4.47 & 1.74 & 1.76 & 0.407 & 0.411 \\
\hline & & 19.21 & 19.41 & 4.60 & 4.62 & 1.83 & 1.86 & 0.400 & 0.403 \\
\hline \multicolumn{2}{|l|}{ LSD at $5 \%$} & 0.69 & 0.90 & 0.25 & 0.20 & 0.11 & 0.13 & NS & 0.006 \\
\hline \multicolumn{10}{|c|}{ C : Interaction effect of irrigation intervals and antitranspirants source } \\
\hline \multirow{4}{*}{10 days } & Water & 16.53 & 16.71 & 4.00 & 4.03 & 1.61 & 1.64 & 0.390 & 0.394 \\
\hline & Kaolin & 17.41 & 17.65 & 4.33 & 4.36 & 1.64 & 1.67 & 0.381 & 0.383 \\
\hline & $\mathrm{K}_{2} \mathrm{SiO}_{3}$ & 18.52 & 18.68 & 4.45 & 4.46 & 1.75 & 1.77 & 0.366 & 0.369 \\
\hline & Dyriton & 19.43 & 19.56 & 4.63 & 4.66 & 1.86 & 1.89 & 0.351 & 0.355 \\
\hline \multirow{4}{*}{20 days } & Water & 16.39 & 16.58 & 3.97 & 3.99 & 1.58 & 1.60 & 0.471 & 0.477 \\
\hline & Kaolin & 17.21 & 17.48 & 4.30 & 4.32 & 1.61 & 1.64 & 0.450 & 0.452 \\
\hline & $\mathrm{K}_{2} \mathrm{SiO}_{3}$ & 18.31 & 18.39 & 4.40 & 4.42 & 1.72 & 1.75 & 0.420 & 0.423 \\
\hline & Dyriton & 19.10 & 19.29 & 4.58 & 4.61 & 1.82 & 1.84 & 0.410 & 0.413 \\
\hline \multicolumn{2}{|c|}{ LSD at $5 \%$} & 0.49 & 0.35 & 0.22 & N.S & N.S & N.S & 0.011 & N.S \\
\hline
\end{tabular}

r. 10 
Rakha, M.K.A.

Table (4): Effect of irrigation intervals, antitranspirants and their interaction on yield and its components of eggplants during seasons of 2012 and 2013.

\begin{tabular}{|c|c|c|c|c|c|c|c|c|c|c|c|}
\hline \multirow{2}{*}{ Treat. } & \multirow[t]{2}{*}{ Char. } & \multicolumn{2}{|c|}{$\begin{array}{l}\text { No. of fruits / } \\
\text { plant }\end{array}$} & \multicolumn{2}{|c|}{$\begin{array}{c}\text { Average yield / plot } \\
(\mathrm{kg})\left(12.8 \mathrm{~m}^{2}\right)\end{array}$} & \multicolumn{2}{|c|}{$\begin{array}{l}\text { Early yield } \\
\text { (ton/fed.) }\end{array}$} & \multicolumn{2}{|c|}{$\begin{array}{l}\text { Total yield } \\
\text { (ton/fed.) }\end{array}$} & \multicolumn{2}{|c|}{$\begin{array}{c}\text { Relative increase yield } \\
\%\end{array}$} \\
\hline & & $1^{\text {st }}$ & $2^{\text {nd }}$ & $1^{\text {st }}$ & $2^{\text {nd }}$ & $1^{\text {st }}$ & $2^{\text {nd }}$ & $1^{\text {st }}$ & $2^{\text {nd }}$ & $1^{\text {st }}$ & $2^{\text {nd }}$ \\
\hline \multicolumn{12}{|c|}{ A : Irrigation period } \\
\hline 10 days & & 6.40 & 6.51 & 67.28 & 68.20 & 7.29 & 7.38 & 21.03 & 21.31 & & \\
\hline 20 days & & 6.33 & 6.42 & 66.94 & 67.51 & 7.22 & 7.31 & 20.92 & 21.10 & & \\
\hline LSD & & 0.11 & 0.08 & 1.97 & 2.11 & 1.3 & 1.5 & 2.3 & 2.7 & & \\
\hline \multicolumn{12}{|c|}{ B: Antitranspirants source } \\
\hline Water & & 5.89 & 5.93 & 62.33 & 62.85 & 6.33 & 6.42 & 19.48 & 19.61 & & \\
\hline Kaolin & & 6.03 & 6.19 & 64.45 & 65.10 & 7.16 & 7.20 & 20.16 & 20.34 & 3.49 & 3.72 \\
\hline $\mathrm{K}_{2} \mathrm{SiO}_{3}$ & & 6.62 & 6.73 & 67.64 & 68.57 & 7.68 & 7.84 & 21.14 & 21.43 & 8.52 & 9.28 \\
\hline Dyriton & & 7.12 & 7.31 & 70.69 & 71.07 & 8.10 & 8.21 & 22.09 & 22.21 & 13.40 & 13.26 \\
\hline LSD at $5 \%$ & & 0.18 & 0.04 & 3.98 & 4.10 & 2.3 & 3.5 & 3.6 & 2.8 & & \\
\hline \multicolumn{12}{|c|}{$\mathrm{C}:$ Interaction effect of irrigation intervals and antitranspirants source } \\
\hline \multirow{4}{*}{10 days } & Water & 5.91 & 5.97 & 62.43 & 63.01 & 6.35 & 6.40 & 19.51 & 19.69 & & \\
\hline & Kaolin & 6.12 & 6.28 & 64.71 & 65.54 & 7.19 & 7.24 & 20.22 & 20.48 & 3.64 & 4.01 \\
\hline & $\mathrm{K}_{2} \mathrm{SiO}_{3}$ & 6.53 & 6.70 & 68.73 & 69.32 & 7.72 & 7.89 & 21.48 & 21.66 & 10.10 & 10.01 \\
\hline & Dyriton & 7.23 & 7.41 & 71.07 & 72.00 & 8.27 & 8.32 & 22.21 & 22.50 & 13.84 & 14.27 \\
\hline \multirow{4}{*}{20 days } & Water & 5.72 & 5.85 & 61.73 & 62.34 & 6.31 & 6.41 & 19.29 & 19.48 & & \\
\hline & Kaolin & 6.00 & 6.10 & 64.35 & 65.02 & 7.14 & 7.18 & 20.11 & 20.32 & 4.25 & 4.31 \\
\hline & $\mathrm{K}_{2} \mathrm{SiO}_{3}$ & 6.50 & 6.62 & 67.52 & 68.44 & 7.62 & 7.82 & 21.10 & 21.40 & 9.38 & 9.86 \\
\hline & Dyriton & 7.10 & 7.20 & 69.76 & 70.40 & 7.97 & 8.10 & 21.80 & 22.00 & 13.01 & 12.94 \\
\hline \multicolumn{2}{|c|}{ at $5 \%$} & N.S & N.S & 5.03 & 4.95 & 2.91 & 2.10 & 2.9 & 3.4 & & \\
\hline
\end{tabular}


J. Plant Production, Mansoura Univ., Vol. 5 (12), December, 2014

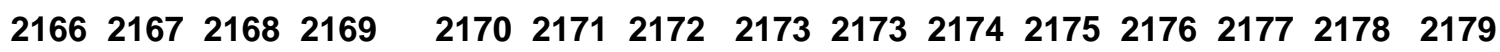

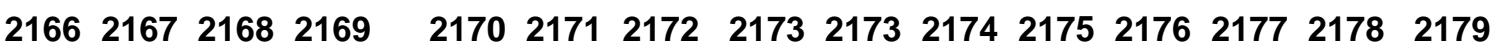

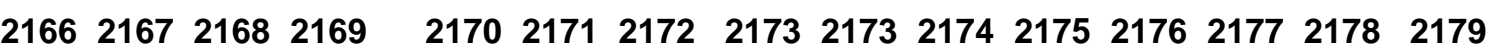

$$
r \cdot \Lambda V
$$

